\title{
POTRET KORUPTOR DALAM NOVEL KORUPSI
}

\author{
Ni Nyoman Subardini \\ Badan Pengembangan dan Pembinaan Bahasa \\ Email: ninyomansubardini@yahoo.co.id \\ HP: 08121368882
}

\begin{abstract}
This paper aims to describe about of fenomena corruption in two novels. The method of research used is qualitative description method. The novels being discussed are Korupsi written by Pramoedya Ananta Toer (2002), and Korupsi (translation) written by Tahar Ben Jelloun (2010). Under the descriptive study by using continually reading technique, it was identified that there are information about corruption. One's acts are closely related to the place or the invironment where she/he lives. This statement is relevant with concept of "Sosiologi is objektif study and scientific approach about society and man, study about social process and institution" by Sapardi Djoko Damono (1979). By using the sociological approach of literature, the study shows that corruption committed by the main character of Korupsi caused by poverty and the opportunity possessed by a public servant. With this assumption, we can make the novel as a document in expressive research.

Based on the analysis report, it is found out that corruption in a phenomenon that has been cultured in the society. Corruption is a phenomenon is as old as human life. Corruption phenomenon has taken place in various forms and society or countries. In its history, corruption by society is condidered as a natural thing in everyday life.
\end{abstract}

Key words: novel, corruption, sosiology literature

\begin{abstract}
ABSTRAK
Penelitian ini bertujuan mendeskripsikan fenomena korupsi dalam dua novel. Metode penelitian yang digunakan dalam penelitian ini adalah metode deskriptif kualitatif. Novel yang dibicarakan adalah Korupsi karya Pramoedya Ananta Toer (2002), dan Korupsi (terjemahan) karya Tahar Ben Jelloun (2010). Mendeskripsikan dengan teknik membaca berulang-ulang, akan dapat mengidentifikasikan keterangan tentang korupsi. Pendekatan yang dipergunakan adalah sosiologi sastra, suatu analisis teks untuk mengetahui strukturnya, untuk kemudian dipergunakan memahami lebih dalam lagi gejala sosial yang ada di luar sastra (Damono, 1979). Berdasarkan hasil analisis diperoleh korupsi sebagai fenomena yang telah membiadab di masyarakat. Korupsi sebagai suatu gejala sosial telah berada setua dengan umur umat manusia. Fenomena korupsi telah mengambil tempat pada berbagai bentuk dan terdapat pada berbagai masyarakat atau bangsa. Dalam sejarahnya, korupsi oleh masyarakat dianggap sebagai sesuatu yang wajar atau lazim dalam kehidupan sehari-hari.
\end{abstract}

Kata kunci: novel, korupsi, sosioliogi sastra

\section{PENDAHULUAN}

Korupsi sudah berlangsung lama. Di berbagai negara, tak terkecuali di negara-negara maju sekali pun. Semakin berkembangnya sektor ekonomi dan politik serta semakin majunya usaha-usaha pembangunan dengan pembukaan-pembukaan sumber alam yang baru, maka semakin kuat dorongan individu terutama di kalangan pegawai negeri untuk melakukan praktik korupsi dan usaha-usaha penggelapan seperti terjadi pada kasus Hambalang di Indonesia.

Istilah korupsi hadir pertama kali dalam khasanah hukum Indonesia dalam Peraturan Penguasa Perang Nomor Prt/Perpu/013/1958 tentang Peraturan Pemberantasan Korupsi. Kemudian, dimasukkan juga dalam Undang-Undang Nomor 24 (Prp/1960 tentang Pengusutan Penuntutan dan Pemeriksaan Tindak Pidana Korupsi. Undang-undang ini 
kemudian dicabut dan digantikan oleh Undang-undang Nomor 3 Tahun 1971 tenang Pemberantasan Tindak Pidana Korupsi, yang kemudian sejak tanggal 16 Agustus 1999 digantikan oleh Undang-undang No.31 Tahun 1999 dan akan mulai berlaku efektif paling lambat dua tahun kemudian (16 Agustus 2001) dan kemudian diubah dengan Undang-undang Nomor 20 Tahun 2001 tanggal 21 November 2001 (Darwan Prinst).

Berbagai survei yang dilakukan lembaga asing seperti Global Corruption Indeks atau Transparency International Index dan beberapa lembaga survei dalam negeri, menunjukkan bahwa Indonesia termasuk peringkat teratas dalam peringkat korupsinya. Bahkan, tindak pidana korupsi tidak lagi terpusat di Jakarta, tetapi menyebar ke seluruh daerah, menjadi penumpang gelap dalam proses otonomisasi dan desentralisasi. Sejak 1992 hingga 2000 menurut International Country Risk Guide Index (ICRGI), Indeks korupsi di Indonesia terus meningkat dari sekitar tujuh menjadi hampir sembilan pada tahun 2000.

Pada saat gerakan reformasi dikumandangkan di Indonesia, tepatnya pada tanggal 21 Juni 1998, sebuah organisasi nonpemerintah (ornop) dibentuk oleh orang-orang seperti Adi Adjono Sutjipto, Chritianto Wibisono, Eros Djarot, Daniel Dhakidae, Masdar F. Mas'udi, Munir (alm.), Teten Masduki, T. Mulya Lubis, dan lain-lain yang terkenal kental berjuang dengan integritas dan komitmen yang tinggi akan pemerintahan yang demokratis, transparan, dan bersih dari KKN. Ornop ini yang kemudian cukup terkenal denan komitmennya memberantas korupsi dengan nama Indonesian Corruptian Watch (ICW) (Zon, 2004:2 - 6).

ICW mengklaim bahwa pemerintahan di bawah tangan Soeharto sebagai pemimpinnya, keluarga, sahabat serta kroni-kroninya mewarisi segudang masalah korupsi yang gawat. Korupsi tidak saja mendominasi wilayah eksekutif dan yudikatif, tetapi juga lembaga legislatif hampir pada semua tingkatannya. Pendek kata, nyaris tidak ada ruang yang bebas dari korupsi. Realitas ini diterima sebagai bagian dari kebudayaan yang menyimpang. Kehidupan ekonomi yang nyaris melumpuhkan kehidupan masyarakat Indonesia pada tahun 1997, banyak yang menuding dipicu atau diperburuk oleh masalah korupsi, kolusi, dan nepotisme.

Korupsi sebagai fenomena penyimpangan dalam kehidupan sosial budaya, kemasyarakatan, dan kenegaraan sudah dikaji dan ditelaah secara kritis oleh banyak ilmuwan dan filosof. Aristoteles misalnya, yang diikuti oleh Machiavelli, sejak awal telah merumuskan sesuatu yan disebutnya sebagai korup moral (Hasibuan, 1997:342-347). Korupsi moral merujuk pada bentuk konstitusi yang sudah melenceng, hingga para penguasa rezim termasuk dalam sistem demokrasi, tidak lagi dipimpin oleh hukum, tetapi tidak lebih hanya berupaya melayani diri sendiri.

Korupsi berasal dari kata Latin Corruptio atau Corruptus. Kemudian, muncul dalam bahasa Inggris dan Prancis Corupption, dalam bahasa Belanda Korruptie, selanjutnya dalam bahasa Indonesia dengan sebutan Korupsi (Hamzah, 1985:2-3). Alatas (1987: viii) menandaskan esensi korupsi sebagai pencurian melalui penipuan dalam situasi yang mengkhianati kepercayaan. Korupsi merupakan perwujudan immoral dari dorongan untuk memperoleh sesuatu dengan metode pencurian dan penipuan. Titik penting yang igin diletakkannya di sini, juga mencakup dua bentuk korupsi yang sulit untuk dimasukkan dalam kebanyakan peristilahan korupsi, yaitu nepotisme dan korup otogenik (dilakukan seorang diri). Sementara itu, Bank Dunia membatasi pengertian korupsi hanya pada, "Pemanfaatan kekuasaan untuk mendapat keuntungan pribadi". Ini merupakan definisi yang sangat las dan mencakup tiga unsur korupsi yang digambarkan dalam akronim KKN (Korupsi, Kolusi, dan Nepotisme) (Kusuma, 2003:12).

Dalam Korupsi karya Pramoedya Ananta Toer diterbitkan pertama kali tahun 1954 dan diterbitkan ulang tahun 2002 oleh Hasta Mitra. Novel yang terdiri atas 14 bab ini menceritakan tentang seorang pegawai negeri bernama Bakir yang melakukan korupsi. Awalnya, ia melakukan korupsi karena desakan ekonomi keluarga, tetapi lama kelamaan ia 
semakn rajin melakukan korupsi sehingga ia menjadi kaya raya. Ia terjerumus ke dalam pergaulan tingkat atas yang penuh kepalsuan dan kemewahan tanpa makna, yang membuat jiwanya kian hampa. Pada akhirnya, segala kejahatannya terbongkar dan ia pun terpuruk dalam penjara. Dalam Korupsi karya Tahar Ben Jelloun diterbitkan tahun 1994 dengan judul L'Homme Rompu (Lelaki yang Patah) diterjemahkan oleh Okke KS Zaimar dan diterbitkan oleh Penerbit Serambi tahun 2010 menceritakan seorang tokoh bernama Murad (aku) yang awalnya sangat memegang prinsip hidupnya untuk tidak korupsi. Ia bekerja di Institusi Kementerian Pekerjaan Umum, Casablanca, Maroko. Kendati tahu bahwa lingkungan di sekelilingya sangat rentan dengan urusan korupsi, ia tetap kukuh akan pendiriannya bahwa melakukan tindakan korupsi sangat tercela. Murad, juga seorang pegawai negeri sama seperti tokoh Bakir. Ia memiliki kesempatan untuk mengambil untung dari tugas yang diembannya. Sebagai pegawai negeri sipil dengan gaji yang rendah, ia tertekan karena impitan kemiskinan dan ingin menyenangkan keluarga. Akhirnya, ia tergiur, benteng kukuh akan pendiriannya runtuh. Murad melakukan korupsi juga. Pram dan Jelloun berusaha menyajikan sebuah fenomena sosial tentang perilaku tokoh Bakir dan tokoh Murad melakukan tindak pidana korupsi. Novel-novel tersebut sangat tepat dipublikasikan di Indonesia. Sebab saat ini masyarakat sungguh merasakan, korupsi sudah menjadi penyakit peradaban yang sulit diberantas. Kendati ada Komisi Pemberantasan Korupsi (KPK) dan institusi terkait yang mencoba untuk mengatasi korupsi masih mewabah.

Berkenaan dengn pembahasan tentang masalah korupsi yang digambarkan oleh Toer dan Jelloun melalui novelnya tersebut, muncul beberapa pertanyaan dan harus dijawab, yaitu bagaimana korupsi timbul pada masyarakat, mengapa seseorang (yang diwakili oleh tokoh utama) melakukan korupsi, dan apakah harta yang berlebih dari hasil korupsi menyebabkan seseorang menjadi lebih tenang hidupnya.

Bertolak dari pembicaraan masalah korupsi di atas, pendekatan yang digunakan dalam kajian ini adalah pendekatan sosiologi, khususnya pradigma yang dikemukakan oleh Sapardi Djoko Damono. Sosiologi merupakan suatu sistem ilmu pengetahuan yang berusaha untuk mempelajari proses dalam masyarakat dan mencoba menemukan hukum-hukum yang menguasai proses tersebut. Sastra juga mempunyai objek yang sama dengan sosiologi yaitu manusia. Manusia yang hidup dalam masyarakat, bagaimana manusia sebagai individu maupun secara berkelompok berinteraksi dan berhubungan dengan individu dan kelompok lain, dan usaha manusia untuk mengubah masyarakat itu. "Sastra menampilkan gambaran kehidupan; dan kehidupan itu sendiri adalah suatu kenyataan sosial (Damono, 1979:1)". Oleh karena itu, pengkajian ini bertujuan menggambarkan fenomena korupsi yang terdapat dalam karya sastra (novel) dengan menggunakan pendekatan sosiologi sastra, yang memandang karya sastra sebagai sebuah fenomena kemasyarakatan. Ada dua kecenderungan utama dalam kajian sosiologis terhadap sastra, yaitu pertama pendekatan yang berdasarkan pada anggapan bahwa sastra merupakan cermin proses sosial-ekonomis belaka. Pendekatan ini bergerak dari faktor-faktor di luar sastra untuk membicarakan sastra; sastra hanya berharga dalam hubungannya dengan faktor-faktor di luar sastra itu sendiri. Jelas bahwa dalam pendekatan ini teks sastra tidak dianggap utama, ia hanya merupakan epiphenomenon (gejala kedua). Kedua, pendekatan yang mengutamakan teks sastra sebagai bahan pengkajian. Metode yang dipergunakan dalam sosiologi sastra ini adalah analisis teks untuk mengetahui strukturnya, untuk kemudian dipergunakan memahami lebih dalam lagi gejala sosial yang di luar sastra (Damono, 1979: 2-3).

Sikap masyarakat atau manusia Indonesia yang pasif dan bahkan cenderung akomodatif serta cenderung memberi ruang gerak yang cukup lapang terhadap terjadinya korupsi, kolusi, nepotisme, dan berbagai penyimpangan lainnya. Kekuasaan dapat diasumsikan akan cenderung korup dan absolute, apabila potensi dan daya kritis manusianya sangat lemah, yang berakibat posisinya tersubordinasi dan korupsi kian merajalela. 
Kuntowijoyo (1994: 62) menyatakan dalam sebuah sistem sosial, kebudayaan dapat mempunyai hubungan affirmative atau critical terhadap kekuasaan. Apabila kebudayaan itu semata-mata bertindak sebagai pengukuh kekuasaan, hubungan tersebut disebut affirmative. Sebaliknya, jika kebudayaan mampu berperan sebagai pengawas terhadap kekuasaan, disebut critical.

Korupsi, kolusi, nepotisme, dan berbagai penyimpangan kekuasaan lainnya tetap saja eksis dan bahkan cenderung tambah mewabah di semua institusi vital kekuasaan, dari pusat hingga ke daerah-daerah, dari pelayanan yang bersifat privat hingga pelayanan publik, dari hirarki tertinggi hingga terendah, dari korupsi milyar dan trilyunan rupiah hingga korupsi ala kadarnya yang hanya bernilai puluhan atau raturan ribu rupiah.

Berbagai penyimpangan tersebut dapat bertahan karena budaya politik dan partisipasi masyarakat hanya cenderung affirmative, pasif, dan tidak kritis. Korupsi adalah penyimpangan yang berakar dari watak koruptif manusia yang tidak terkontrol, berupa hasrat akan kekayaan dan kekuasaan yang menghalalkan segala cara dan otoritas yang tidak transparan.

Korupsi sebagai perilaku politik yang melibatkan birokrat dan militer, tidak terlepas dari faktor budaya politik dan latar belakang karakter manusia Indonesia. Budaya politik dalam sejumlah teori dan pendapat ahli tidak terlepas dari faktor nilai, norma, pengetahuan, adat istiadat, mitos, etos, dan ideologi. Diasumsikan apabila nilai, norma, pengetahuan, adat istiadat, mitos, etos, dan ideologi itu dipatuhi, maka semestinya tidak terjadi korupsi. Namun, para birokrat dan militer cenderung memanipulasi budaya politik tersebut. Akibatnya, korupsi merajalela.

Beberapa definisi diberikan Benveniste (1989: 167-169) dengan sangat rinci mengenai korupsi dan tindak korupsi dapat dipetakan dalam empat definisi besar, sebagai berikut.

1. Deiscretionery corruption, merupakan korupsi yang dilakukan karena adanya kebebasan dalam menentukan kebijakan, sekalipun tampaknya bersifat sah, bukanlah praktik-praktik yang dapat diterima oleh para anggota organisasi.

2. Illegal corruption, merupakan korupsi tindakan yang membongkar atau mengacaukan bahasa atau pun maksud-maksud hukum, peraturan dan regulasi tertentu. Efektivitas untuk jenis korupsi ini bisa diukur. Namun, ia jauh lebih mudah untuk dikendalikan.

3. Mercenery corruption, merupakan korupsi dengan maksud untuk memperoleh keuntungan individual/pribadi. Biasanya korupsi ini banyak digunakan oleh para competitor politik dalam suksesi ataupun kampanye politik.

4. Ideological corruption, merupakan korupsi yang dilakukan lebih karena kepentingan kelompok, karena komitmen ideologis seseorang yang mulai tertanam di atas nama kelompok tertentu. Biasanya, korupsi ini amat sulit untuk dideteksi atau diketahui landasannya secara material. Seseorang yang telah didoktrin pada sebuah pandangan, lebih rela mati atas nama symbol atau tanda tertentu di dalam kelompok yang dinilai sakral, dibandingkan seseorang itu harus lari bila berhadapan dengan bahaya yang mengancam jiwanya.

Demikian mengenai korupsi, berhubungan baik secara individual maupun di dalam sistem sosial. Seseorang dapat benar-benar memperlakukan tindak korupsi sebagai aksi individual, bila sebuah ssstem sosial tidak lagi memberikan jalan baginya untuk dapat eksis di dalam sistem itu. Dalam cara pandang yang berbeda, justru system sosiallah yang menjerat orang-orang di dalamnya untuk melakukan tindak-tindak korupsi. Bisa jadi, karena sistem yang terlanjur terlahir dalam kebekuan dan kerumitan jalur pada kerangka operasionalnya.

Dapat dibelinya orang-orang yang memegang kekuasaan adalah merupakan sebab musabab korup paling dasar. Mereka yang memegang kekuasaan termasuk orang-orang di sektor-sektor baik pemerintahan maupun swastra di semua lapisan masyarakat. 
Meluasnya kekuasaan pada masing-masing pihak berbeda-beda dan inilah yang menunjukkan lebih pentingnya satu terhadap yang lain dalam hal penentuan sebab-musabab korupsi yang paling akhir. Mereka yang menjalankan kekuasaan di puncak masyarakatlah yang paling penting. Jika mereka melakukan korupsi atau menenggang korupsi, masyarakat selebihnya akan menyerah kepada penyakit itu. Karena, pemimpin politik yang korup tidak akan mempunyai kekuatan moral untuk memerangi korupsi, yang berjangkit di kalangan pegawai pemerintah di tingkat bawah.

\section{METODE PENELITIAN}

Penelitian merupakan pengkajian deskripsi kualitatif karena hanya mendeskripsikan hal yang ada dalam data, bukan menguji suatu hipotesis. Sumber data yang digunakan novel Korupsi (2002) karya Pramoedya Ananta Toer, dan novel Korupsi (terjemahan, 2010) karya Tahar Ben Jelloun dalam pengkajian ini dikumpulkan dengan cara membaca secara intensif. Kemudian melakukan pengkodean, pengklasifikasian, penginterpretasian dan penganalisisan data sesuai dengan rumusan masalah.

\section{HASIL PEMBAHASAN Koruptor dalam Novel}

Dalam novel Korupsi karya Pramoedya Ananta Toer diceritakan oleh seorang pencerita aku, tetapi merupakan contoh jelas tentang karya yang penceritanya tidak mungkin diidentifikasikan dengan pengarangnya si aku ini adalah pegawai kawakan di Jakarta yang tidak sanggup lagi memelihara anak istri dengan gajinya karena inflasi yang makin parah dan keadaan ekonomi yang makin buruk. Ia memilih satu-satunya jalan keluar yang juga sudah ditempuh oleh sekian banyak teman sekerjanya: korupsi. Pilihan itu merombak seluruh hidupnya ia berkembang menjadi koruptor yang berjaya dan menikmati segala plesiran kehidupan kota besar, antara lain ia mengambil bini muda yang cantik. Namun dengan segala suksesnya, ia tidak berbahagia. Akhirnya ia ditangkap dan ditahan, dan dalam penjara ia berangsur-angsur mencapai kesimpulan bahwa ia termasuk angkatan yang sia-sia dan konyol, yang ketularan basil kolonial, dan yang sebaiknya lenyap dari dunia saja.

Bakir seorang pegawai negeri tinggal di Jakarta bersama seorang istri, Mariam dan tiga orang anak yang masih bersekolah. Selama bertahun-tahun Bakir bekerja keras dengan penuh pengabdian. Meskipun demikian, keadaan ekonomi keluarganya tidak membaik. Bahkan sebagian lahan dirumahnya disewakan kepada seorang tauke sebagai tempat usaha untuk menutup kebutuhan keluarga. Istrinya pun terpaksa menjual barang-barang miliknya untuk membeli lauk pauk. Sadar dengan keadaan ekonominya, Bakir berusaha mencari jalan untuk mendapatkan uang tambahan. Dengan memanfaatkan kedudukannya sebagai kepala bagian, ia mulai menjual barang-barang milik kantor. Selanjutnya, ia pun berani meminta komisi untuk pengadaan barang dikantornya. Pada saat Bakir membawa uang komisinya ke rumah, istrinya sangat marah, membuat Bakir meninggalkan rumah. Ia beranggapan bahwa istrinya tidak pandai bersyukur. Sebaliknya, Mariam merasa bahwa tindakan suaminya, merupakan perbuatan korupsi yang dibencinya. Ia sangat sedih dan membiarkan suaminya pergi.

Bakir kemudian menuju rumah Sutijah, perempuan bekas tetangganya yang sudah pindah ke rumah yang lebih sempit bersama ibunya. Selanjutnya mereka tinggal serumah. Bakir lalu menjadi kaya-raya dan tinggal di sebuah rumah besar di daerah Bogor dengan Sutijah dan anak mereka yang masih balita. Usia Bakir yang jauh lebih tua daripada Sutijah membuatnya tidak mampu mengikuti kegiatan Sutijah bersenang-senang bersama temantemannya. Pada saat Sutijah berlibur ke Bali dan kehabisan bekal ia meminta Bakir untuk mengirimkan uang. Ketika Bakir berada di kantor pos untuk mengirim uang bagi istrinya, salah seorang pegawai kantor pos mencurigainya karena uang yang dibawa Bakir diduga 
uang palsu. Bakir kemudian ditangkap dan dipenjara. Ketika ditangkap itulah, istri, anakanak, dan asistennya bernama Sirad menengok Bakir. Kedatangan mereka untuk meyakinkan bahwa perjuangan melawan korupsi akan tetap mereka lanjutkan.

Perbuatan yang dapat memberikan keuntungan ekonomi pada pihak-pihak yang berkepentingan dengan jalan melanggar seperti perizinan, pengesahan suatu peraturan, dan sebagainya. Korupsi dalam pengertian inilah yang dilakukan Bakir. Ia berwenang untuk mengeluarkan izin pengadaan barang untuk kantornya. Dengan jabatannya tersebut, Bakir yang pada awalnya memiliki idealisme tinggi mulai tergoda untuk menyelewengkan kepercayaan. Pada awal kariernya, Bakir sangat bangga pada profesinya karena ia dapat meneruskan karier ayah dan kakeknya. Ia pun berharap anak-anaknya bisa menjadi pegawai negeri kelak. Karena menjadi pegawai negeri adalah suatu kehormatan dan kebesaran.

Kesadaran bahwa penghasilannya semakin tidak mencukupi, membuat Bakir kemudian bertekad untuk korupsi. Pada awalnya ia pergi ke Pasar Senen untuk menjual kertas serta alat tulis lain milik kantornya pada seorang tauke pedagang barang bekas. Uang yang didapat tidak seberapa. Dengan uang dua puluh rupiah di kantongnya, Bakir berencana memperbaiki penampilannya demi mencari mangsa yang lebih besar. Sasaran berikutnya adalah N.V. Muria dengan presiden direktur Thiaw Lie Ham. Lagi-lagi seorang tauke. Di perusahaan tersebut Bakir melakukan transaksi pengadaan pakaian. Setelah transaksi terjadi. Bakir meminta sebagian uang komisinya, sedangkan sisanya akan diantar ke rumah. Jabatan dan kekuasaan yang dimiliki Bakir memungkinkannya memperluas jaringan korupsinya. Demikian pula latar cerita yang berlangsung di Jakarta sebagai ibukota negara dan sebagai pusat kekuasaan menunjukkan bahwa korupsi muncul seiring dengan kekuasaan karena semakin seseorang dekat dengan kekuasaan, maka godaan dan kesempatan untuk melakukan korupsi semakin besar, seperti tokoh Bakir yang bekerja di sebuah kantor pemerintah di Jakarta.

Penghasilan bulanan yang tidak cukup serta kesempatan yang terbuka membuat para pegawai merasa bahwa tindakan mereka untuk korupsi seolah-olah memang wajar dilakukan. Begitu juga yang sudah diniatkan oleh Bakir sejak lama bahwa kalau hanya mengandalkan gaji setiap bulan sebagaimana pada zaman kolonial, seorang pegawai seperti dirinya tidak akan dihormati dan hidup sengsara (Toer, 2002: 5). Bila dirunut dari peristiwa sejarah, pada era lima puluhan, krisis ekonomi tengah melanda negeri ini dengan inflasi yang tinggi. Masa peralihan dari masa penjajahan ke masa kemerdekaan juga turut mempengaruhi mental masyarakat. Generasi tua seperti Bakir yang merasa telah cukup mengabdi pada profesinya, harapan kehidupan yang lebih baik bukanlah sesuatu yang mustahil tetapi kenyataan yang ada di depan mata sangat bertolak belakang. Penghasilan bulanan yang tidak cukup untuk memenuhi kebutuhan menjadikannya seseorang yang memiliki kesempatan untuk melakukan korupsi. Keyakinan Bakir bahwa dirinya sudah dua puluh tahun lamanya mengabdi di kantor pemerintah makin membulatkan niatnya untuk menyalahkgunakan kekuasaan. Baginya, korupsi merupakan imbalan atas kerja kerasnya. Tidaklah mengherankan apabila Bakir tampak begitu rakus dan agresif dalam mencari peluang melakukan korupsi.

Keadaan ekonomi keluarga yang makin merosot, tidak seimbang dengan jabatan tinggi yang diembannya di kantor. Rumahnya pun sempit karena disewakan pada saudagar Tionghoa demi menutup kebutuhan keluarga. Kondisi ekonomi yang memprihatinkan dan penampilan yang tidak mentereng menjadikan Bakir tidak dihormati oleh para pegawai yang lebih rendah kedudukannya. Oleh karena itu, niat Bakir untuk memulai perbuatan korupsinya dianggap sudah selayaknya dilakukan karena sudah menjadi rahasia umum bahwa seorang pegawai negeri mustahil dapat hidup layak tanpa melakukan korupsi. Apabila ia tidak melakukannya, kesempatan itu akan diambil oleh orang lain, seperti dapat dibaca pada kutipan berikut. 
“... Aku harus segera jual barang-barang curian ini di Senen. Tetapi ini semua toh bukan barang curian. Ini semua adalah hakku, karena kalau tidak kuambil, pegawai-pegawai lainlah yang akan mengerjakannya ... (Toer, 2002: 16-17).”

Lingkungan yang korup pada rekan-rekan kerjanya membuat Bakir tidak ragu untuk mewujudkan niatnya. Pedagang kertas bekas di Pasar Senen, salah satu pasar di Jakarta yang terkenal dengan pedagang-pedagang bekas pun seorang paham betul bahwa pegawai kantor seperti Bakir sering datang padanya. Mereka menukarkan sebagian persediaan alat tulis milik kantor yang telah dicuri dengan uang yang tidak seberapa demi menutup kebutuhan pribadi.

Meskipun niat untuk korupsi telah bulat, hati nurani Bakir tetap terusik. Di satu sisi benaknya, ia harus mencari peluang bagaimana caranya korupsi, tetapi di bagian lain ia beranggapan bahwa sejarah akan ternoda (Toer, 2002: 12). Rasa takut terhadap hukuman Tuhan sedikit membuatnya ragu untuk mengawali pencurian alat tulis milik kantor. Barangkali ia teringat bimbingan orang tua yang memberinya contoh untuk berlaku dan berpikir sesuai tuntunan agama.

Keberhasilan demi keberhasilan dalam berkorupsi membuat Bakir dapat hidup mewah tinggal di rumah bagus di Bogor dengan seorang istri muda. Pergaulannya pun tidak lagi dengan orang kebanyakan tetapi dengan sesama koruptor. Ia juga menjadi anggota kelompok koruptor yang harus saling menjaga rahasia tindakan mereka.

Dari gambaran tentang tokoh Bakir yang melakukan korupsi dapat diketahui bahwa pada hakikatnya korupsi dapat muncul karena adanya keinginan dan kesempatan yang terjadi secara bersamaan. Keinginan untuk korupsi didorong oleh kesadarannya bahwa keadaan ekonomi keluarganya tidak semakin membaik meskipun Bakir telah bekerja keras selama puluhan tahun dengan dedikasi dan kejujuran yang tinggi. Faktor kesempatan juga dimiliki oleh Bakir dalam mengembangkan korupsinya. Rekan-rekan seperjuangan yang sebetulnya tidak lebih berjuang melawan penjajah daripada Bakir kehidupannya justru lebih makmur.

Aspek korupsi yang menarik adalah pergeseran yang berlangsung sepanjang ceritanya dari korupsi sebagai masalah moral pribadi menjadi masalah sosial politik dan perbenturan generasi. Secara implisit unsur kedua telah hadir pada awal ceritanya, ketika asisten muda yang masih meyakini cita-cita revolusi mendesak atasanya agar mereka bersama berjuang melawan korupsi, sesuai dengan norma dan nilai revolusi: "Lepas dasi, berkemeja, celana pendek sesuai dengan hawa panas Indonesia, dan - selalu bersikap perwira, bertindak perwira, berpikir perwira. Kita butuh keperwiraan, tidak buruh tikus (Toer, 2002: 60)"'. Akhirnya si aku pencerita bukan lagi individu yang korup: ia termasuk angkatan yang sia-sia, tanpa keperwiraan, angkatan "yang memanjangkan umur penjajahan", pergaulan berdosa dengan sistem kolonial yang terkutuk.

Tentang struktur cerita ini serta teknik naratif yang diterapkan di dalamnya masih perlu dikemukakan beberapa hal. Pertama, tentang korupsi. Mungkin kesan pertama ke arah korupsi protagonist disajikan dengan panjang lebar, kalau bukan bertele-tele, sedangkan bagian kedua, cerita tentang kejayaan awalnya dan keruntuhannya yang menyusul secara tak terhindarnya, digambarkan hampir secara sketsa saja. Namun, dalam pengupasan lebih lanjut susunan cerita yang demikian ini masuk akal: justru langkah pertama itu serba memutuskan. Cara Toer mengembangkan ini cukup menonjol: seakan-akan tegangan pada awal cerita telah ditiadakan, ketika si aku pencerita menyelaskan bahwa telah 'terniat dalam hati'-nya untuk mengerjakan korupsi. Dari awal mulanya tekanan penuh diletakkan pada kata korupsi dan pada obsesi protagonis untuk kata itu sebagai berikut.

\footnotetext{
“... Dan akhirnya terniatlah dalam hati, seperti sudah jamak di masa ini: Korupsi.

Berkali-kali kata itu bergetar dengan hebatnya baik di mulut maupun di hati:
} 
korupsi, korupsi, korupsi. Akhirnya teguhlah niatku untuk mengerjakannya juga. Berdengung kata itu: korupsi, korupsi, korupsi. Tiap dinding dan tiap benda di kamar serasa merasa ikut menggigilkan kata yang itu-itu juga: korupsi! Korupsi! (Toer, 2002: 4)".

Jadi, kata mendahului perbuatan, dosa yang sungguh-sungguh terkandung dalam kata yang menjadi semacam ikon: 'pada awalnya adalah kata'. Juga perbantahan yang keras dengan istrinya dan asistennya, Sirad, berkisar pada kata, seperti misalnya ternyata dari dialog yang singkat berikut.

“Mengapa engkau? Sakit?” tanyaku.

"Engkau tidak berniat, bukan?" tanyanya.

"Berniat? Berniat apa?"

"Korupsi!"

Seperti geledek kata itu menyambar pendengaranku ... (Toer, 2002: 37)”.

Tekanan pada kata yang mendahului perbuatan diungkapkan oleh perkataan yang terus-menerus dipakai: 'niat'. Korupsi dan dosa tidak dimulai dengan perbuatan pertama yang tidak jujur atau menyeleweng, dalam hal ini penjualan alat kantor, melainkan dengan niat untuk melakukan korupsi.

Dalam karya Toer ini menggambarkan dengan jeli dalam gaya satir yang memikat bagaimana penyakit korupsi bisa mewabah secara luas menjadi kebiasaan sosial. Setelah nyaris setengah abad, ternyata novel ini masih sangat relevan dengan problema sosial politik Indonesia dewasa ini. Seperti telah diurai di muka, Toer menulis cerita ini di tahun 1953 hanya delapan tahun setelah kemerdekaan republik ini diproklamasikan — dan kini, di awal abad 21, kita masih saja menghadapi persoalan serupa: para pejabat korup kian menggerogoti uang negara dan rakyat banyak mesti menanggung akibatnya. Seakan-akan, korupsi tak pernah mati.

Novel Korupsi yang ditulis oleh Tahar Ben Jelloun, seorang penulis dan penyair asal Maroko, menuliskan karya-karyanya dalam bahasa Perancis. Novel ini mendapat 'tempat' tersendiri di kalangan sastrawan Indonesia karena karyanya ini terilhami oleh novel Korupsi karya pengarang besar Indonesia bernama Pramoedya Ananta Toer.

Dalam novel Korupsi karya Tahar Ben Jelloun diceritakan tokoh Murad adalah tokoh utama yang ada dalam cerita novel. Ia pegawai negeri yang memiliki kesempatan untuk mengambil untung dari tugas yang diembannya. Ia kuat, tak mau kompromi, dan sangat sadar bahwa korupsi akan membuat kehancuran. Namun sebagai pegawai negeri sipil dengan gaji yang rendah, ia tertekan karena impitan kemiskinan dan ingin menyenangkan keluarga. Istrinya sering mencelanya sebagai kepala keluarga yang tak bisa memakmurkan keluarganya. Hilman (istrinya) membandingkan suaminya dengan asisten Murad bernama Haji Hamid, yang tinggal di vila, punya dua mobil, menyekolahkan anak-anaknya di kedutaan Perancis. Bahkan menghadiahi istrinya jalan-jalan ke Roma. Di sisi lain, lingkungan mendukung. Akhirnya, Murad tergiur, karena kesempatan emas berada di depan matanya. Dari situlah Murad kian goyah dan masuk pada perangkap korupsi ketika ada kesempatan.

“Aku lega! Betapa beratnya ujian itu! Di mana akan kusembunyikan uang itu? Tetapi apakah aku tidak memutuskan akan mengembalikannya kepada Pak Sabbane? Tidak, aku tidak lagi dalam suasana untuk mundur.

... Dia tak akan menanyaiku dari mana asal uang itu. Dia tahu bahwa sebagian besar pegawai negeri menjalankan "kebijaksanaan”! (Jelloun, 2010: 126-127) 
Sebetulnya Murad sangat mengerti, apa yang dilakukannya adalah kesalahan besar. Dia dikuntit rasa bersalah yang teramat dalam, hingga dia terkena penyakit psikosomatis, bercak putih yang kian menyebar karena persoalan psikologis. “... Apa yang bisa kuramalkan dengan adanya bercak-bercak ini? Itu mungkin penyakit psikolgi, tidak... (Jelloun, 2010: 146)". Dia takut korupsi yang dilakukannya diketahui oleh orang lain sehingga dia diadili lalu dibui.

Ternyata ketakutan itu pun benar-benar terjadi. Murad menukarkan uang dollar untuk kedua kalinya, dia diinterogasi oleh tiga orang yang menurut mereka uang tersebut didapatkan dari uang haram. Sejak itu perasaan penuh ketakutan menghantui Murad. Namun yang ternyata tidak demikian. Murad diskors oleh atasannya karena mengambil mesin tik yang sudah usang, bukan karena uang sogokan, seperti tampak dalam kutipan berikut.

"Anda diskors dan dituduh menggelapkan harta rakyat. Pengadilan akan segera memanggil Anda. Saya kira tugas sayalah memberitahukannya kepada Anda dan dengan ini saya menyatakan simpati kepada Anda. Anda selama ini menjadi warga negara yang baik dan seorang pegawai negeri yang hebat. Namun, kita semua mempunyai kelemahan...

... Kalau Anda tidak bersalah, tinggal membuktikannya. Saya tak punya masalah dengan Anda. Tetapi saya bertanggung jawab atas kursi, mesin tik, pulpen, atau orang-orang. Bila orang mengatakan bahwa salah satu dari bawahan saya telah menjual mesin tik, saya terpaksa menindak. Itu normal. Mesin tik itu milik negara, harta rakyat yang dibeli dengan uang dari wajib pajak, dari uang rakyat (Jelloun, 2010: 184)".

Murad seorang insinyur lulusan perguruan tinggi di Perancis yang bekerja di Kementerian Pekerjaan Umum di Casablanca, Maroko. Ia adalah wakil direktur Perencanaan Pembangunan dan Pembinaan (Jelloun, 2010: 15), salah satu tugasnya adalah mempelajari berkas pembangunan yang diajukan ke Kementerian Pekerjaan Umum. Tanpa parafnya tak ada izin membangun. Namun, walau posisinya cukup tinggi penghasilan bulanan Murad tak mencukupi untuk menghidupi istri dan kedua anaknya. Sebenarnya jabatan dan pekerjaannya yang 'basah' sangat memungkinkan ia memperoleh uang suap dari pihak-pihak yang membutuhkan legalitas dari dirinya, namun Murad memiliki prinsip untuk bekerja secara jujur dan tidak melakukan korupsi sehingga di kalangan rekan-rekan kerjanya ia mendapat reputasi sebagai "manusia besi" (Jelloun, 2010: 32).

Sayangnya prinsip yang dipegang teguh oleh Murad tak sejalan dengan istri dan lingkungan kerjanya. Hilman, istrinya selalu mengomel dan menuntut ini dan itu, Hilma juga sering membandingan kehidupan mereka dengan Haji Hamid, asisten Murad yang walau gajinya lebih kecil dari Murad namun Hamid lebih kaya daripada mereka.

“... Pada saat itulah dengan marah istrinya berkata, "Asistenmu itu, dialah laki-laki sejati! Gajinya kurang dari gajimu, tapi dia tinggal di vila yang indah, punya dua mobil, dan anak-anaknya bersekolah di sekolah kedutaan Prancis, tambah lagi dia menghadiahi istrinya liburan ke Roma! Dan kamu menghadiahkan alat kontrasepsi dan kita hanya makan daging dua kali seminggu. Ini bukan hidup namanya. Waktu liburan kita hanya pergi ke rumah ibumu, di rumah tuanya di perkampungan kumuh Fes. Apa kamu sebut itu liburan? Kapan kamu aka sadar bahwa keadaan kita ini menyedihkan?" (Jelloun, 2010: 15-16) 
Keteguhan Murad untuk bekerja secara jujur juga membuat ia menjadi ganjalan bagi rekan-rekan kerjanya yang berusaha mendongkel Murad dari kedudukannya. Ketika atasan maupun asistennya melakukan korupsi maka perilaku Murad yang bersih justru dianggap aneh sampai-sampai direkturnya sendiri memberi wejangan agar Murad lebih 'luwes' dalam bekerja dan memberikan alasan-alasan yang masuk akal agar Murad juga melakukan korupsi seperti mereka.

“... Yang terpenting adalah melakukannya dengan tersembunyi dan, sebisa mungkin, dengan luwes. Itulah yang saya sebut keluwesan. Pemerintah seharusnya berterima kasih kepada segenap rakyatnya yang menolongnya. Mereka adalah orangorang seperti Anda yang menjamin stabilitas dan bahkan kemakmuran negeri. Memang harus diakui bahwa pelaku ekonomi tertentu adalah korban dari praktikpraktik ini, terutama pada bidang pabean dan sistem perpajakan ...

"Praktik yang Anda letakkan pada tingkat moral dan yang Anda sebut korupsi, saya sebut ekonomi parallel. Ekonomi itu bahkan tidaklah tersembunyi, ia betul-betul diperlukan. Saya tidak mengatakan bahwa hal itu baik, saya hanya mengatakan bahwa kita harus memaklumina dan membedakan bahwa 'kompensasi' dan pencurian ... (Jelloun, 2010: 38).”

Kehidupan ekonomi keluarganya yang serba kekurangan, salah satu anaknya yang sakit-sakitan, tekanan dari istri dan rekan-rekan kerjanya yang terus menggodanya agar melakukan korupsi lambat laun mulai menggoyahkan keyakinannya. Iman dan keteguhan prinsipnya benar-benar diuji ketika didalam sebuah berkas yang harus ditandatanganinya terdapat segepok uang dirham, seperti tampak dalam kutipan berikut.

"Berkas itu kubaca-baca. Aku sadar mengapa Haji Hamid menekankan agar aku mempelajarinya. Di antara dua map, ada amplop yang cukup tebal. Tak ada satu tanda pun di situ. Sebuah amplop putih. Amplop itu ditujukan kepada siapa saja dan tidak kepada seorang pun. Aku sudah tahu apa isinya. Tapi kubuka. Dua gepok seratus dan dua ratus dirham. Sepintas lalu jumlahnya dua juta sen. Aku hitung lembar-lembar uang baru itu. Kuhitung lagi (Jelloun, 2010: 68).”

Ketika itu hatinya galau karena uang itu lebih dari cukup untuk melunasi hutang-hutangnya sekaligus untuk mengobati anaknya, namun jika uang itu diambilnya maka runtuhlah prinsip anti suap/korupsi yang selama ini ia pegang teguh.

Pengarang mengemas kisah Murad ini dengan memikat dan begitu hidup, pergolakan batin Murad terdeskripsi dengan sangat baik sehingga pembacanya diajak merasakan kegalauan hatinya dalam mempertahankan prinsipnya. Wejangan panjang lebar dari atasan Murad yang mencoba merasionalisasikan tindakan korupsi terkesan begitu masuk akal dan meyakinkan sehingga tak hanya Murad, tetapi pembaca novel inipun mungkin akan sedikit membenarkan apa yang dikatakan direkturnya itu.

Munculnya tokoh Nadia seorang janda cantik yang merupakan selingkuhan Murad turut mewarnai novel ini. Bagi Murad hanya Nadia yang mengerti akan prinsip yang dianutnya sehingga bisa dikatakan Nadia tempat dimana dia bisa melepaskan ketegangan yang dialaminya baik di rumah maupun di pekerjaannya. Melalui perselingkuhannya dengan Nadia ini, Murad bukan seorang manusia sempurna, di satu sisi ia begitu kokoh mempertahankan prinsipnya sebagai pegawai yang 'bersih' namun di satu sisi ia memiliki kelemahan dalam hal perempuan. Moralitasnya hanya pada negara namun hal ini tidak berlaku dalam hal hubungannya dengan perempuan. 
Pergulatan batin Murad dalam mempertahankan prinsipnya dan bagaimana ketika akhirnya ia harus mengambil resiko atas keputusan yang diambilnya, serta kisah cintanya dengan Nadia mengalir tanpa jeda di novel ini. Sepertinya memang penulis tak memberi kesempatan bagi pembacanya untuk berhenti membacanya karena novel setebal 231 halaman ini ditulis tanpa ada pembagian bab. Untungnya kemahiran pengarang dalam merangkai kisah dengan lugas, tidak bertele-tele ditambah dengan terjemahan yang enak dibaca membuat novel ini memiliki tingkat keterbacaan yang tinggi sehingga beberapa pembaca mungkin akan menghabiskan novel ini dalam sekali duduk.

Novel ini juga merupakan cerminan kehidupan birokrasi masyarakat Indonesia yang dikenal sebagai negara dengan tingkat korupsi yang tinggi karena korupsi sudah mendarah daging dan menjadi sebuah hal yang wajar. Pada akhirnya pengarang memberikan gambaran pada kita bagaimana seorang yang memiliki prinsip yang teguh untuk bekerja secara 'bersih' harus melawan arus dan menghadapi berbagai tekanan dan sistem yang membuat perilaku korupsi menjadi begitu mudah dan mentradisi.

Selain tekanan lingkungan dan sistem, seseorang yang seperti Murad juga bisa dikalahkan oleh karena kemiskinan yang dialaminya, hal ini sesuai dengan apa yang ditulis pengarang dalam kata pengantarnya bahwa "... di bawah langit yang berbeda, dan berjarak beribu-ribu kilometer, ketika didera oleh kesengsaraan yang sama, kadang-kadang jiwa manusia menyerah pada setan yang sama (Jelloun, 2010:12).”

Dari segi keterbacaan, novel ini sangat lugas sehingga mudah untuk dipahami pembaca. Meski demikian, ada persoalan yang cukup mengganggu. Novel ini dimulai dengan memakai sudut pandang orang ketiga. Perubahan tiba-tiba terjadi ketika masuk pada cerita lainnya, yaitu halaman 24 dengan menggunakan sudut pandang "aku".

Konsekuensi dari perubahan sudut pandang ini membuat novel ini jauh lebih memiliki nilai emosi dan pembaca bisa merasakan secara psikologis mengenai orang yang begitu tertekan dan berusaha bertahan atas lingkungan dan di sekelilingnya. Pada waktu tertentu, pengarang juga bermain-main dengan sudut pandang orang kedua. Ia berdialog dengan dirinya sendiri.

Selain sudut pandang, pembaca diteror dengan urusan psikologis. Pada awalnya Murad dipandang oleh tokoh lain sebagai sosok yang baik dan teguh pada pendirian. Hal ini tersurat pada dialog Murad dengan dirinya sendiri, dialog dengan istrinya, juga dengan Nadia (selingkuhan Murad) yang mengaku mencintainya dikarena sifat jujurnya.

Murad sangat mencintai kedua anaknya. Karena berbagai hal, terutama keluarga istrinya, dia mulai tidak suka dengan Hilma, istrinya yang sering "memaksa" dia untuk melakukan hal-hal koruptif yang menurut istrinya sebagai sesuatu yang wajar di era kini.

Ujian yang dialami Muradlah yang membuat novel ini memiliki kekhasan. Pembaca lagi-lagi diteror untuk mengikuti perkembangan perubahan-perubahan sosok Murad. Sosok yang awalnya ideal mulai berubah menjadi sosok yang pragmatis.

Ketika terjadi "sogokan" untuk pertama kalinya, Murad mencari celah untuk memastikan bahwa apa yang dia lakukan tidak sampai merugikan siapa pun. Murad membandingkan dengan orang lain, bahkan dengan "koruptor" di negara maju dengan modus-modus korupsi yang canggih.

Pembenaran yang dilakukan oleh Murad sepertinya menjadi gejala keseharian bagi orang-orang yang mulai masuk pada wilayah korupsi secara evolutif. Awalnya dia mencari celah-celah pembenaran, selanjutnya menjadi ketagihan. Murad tak lagi malu-malu untuk bertanya kepada Haji Hamid mengenai uang sogokan. Murad sudah masuk perangkap korupsi.

Perubahan tokoh Murad kian menjadi ketika dia bisa menikmati hasil korupsinya itu. Misalnya, dia bisa menikmati liburan, pergi ke tempat yang diinginkannya. Mimpi yang tidak pernah terealisasi karena kemiskinan mulai bisa terwujud. 
Sebetulnya, kenikmatan yang dirasakan oleh Murad masih dibayang-bayangi oleh ketakutan-ketakutan. Dia khawatir jika apa yang dilakukannya diketahui orang lain. Pengingkaran dan pembenaran terus-menerus muncul di batinnya sehingga dia memiliki penyakit psikosomatis, sebuah penyakit yang terlihat secara fisik tetapi hanya bisa diobati secara psikologis.

Pengarang cukup cerdas memperlihatkan perubahan-perubahan psikis tokoh Murad. Menjelang berakhirnya cerita ini, Murad sudah benar-benar total dan mulai tenang akan "pekerjaan" barunya sebagai seorang koruptor. Penyakit psikosomatisnya berangsur hilang. Seorang koruptor butuh ketenangan yang luar biasa.

\section{PENUTUP}

Pada hakikatnya, korupsi adalah "benalu sosial" yang merusak struktur pemerintahan, dan menjadi penghambat utama terhadap jalannya pemerintahan dan pembangunan pada umumnya. Dalam praktiknya, korupsi sangat sukar bahkan hampir tidak mungkin dapat diberantas karena sangat sulit memberikan pembuktian yang eksak. Di samping itu, sangat sulit mendeteksinya dengan dasar-dasar hukum yang pasti. Namun, akses perbuatan korupsi merupakan bahaya laten yang harus diwaspadai baik oleh pemerintah maupun oleh masyarakat itu sendiri. Dari kajian terhadap dua novel berjudul Korupsi dengan sudut pandang bahwa "Sastra menampilkan gambaran kehidupan; dan kehidupan itu sendiri adalah suatu kenyataan sosial" dapat disimpulkan bahwa korupsi yang terjadi di dua novel tersebut memiliki pola hubungan antara pejabat di kantor pemerintah dengan pengusaha yang saling menguntungkan secara ekonomi. Meskipun seorang koruptor telah sukses mengumpulkan hartanya, hati nuraninya belum tentu tenang karena ia harus selalu menjaga kebohongankebohongan yang telah dilakukan dengan kebohongan-kebohongan lain.

Dalam dua novel Korupsi digambarkan bahwa baik Bakir maupun Murad berhasil hidup nyaman, tetapi keanggotaannya dalam perkumpulan para koruptor membuktikan bahwa semua hal yang tidak dilakukan dengan kejujuran akan meminta imbalan bahkan menimbulkan ancaman. Bakir atau Murad merupakan gambaran pegawai pemerintah yang di lingkuangan pekerjaannya sarat dengan nuansa korupsi. Dengan menciptakan tokoh Bakir atau tokoh Murad, mungkin pengarang ingin menyindir mental para pegawai yang mudah tergoda melakukan korupsi karena ukuran keberhasilan dan kehormatan seseorang hanya dapat dicapai dengan menunjukkan potensi materinya bukan pada keteguhan imannya.

Kehidupan sosial masyarakat Casablanca dan suasana kota, angkutan umum, lalu lintas, dan perilaku korupsi yang terdapat dalam novel karya Tahar Ben Jelloun ini juga terasa memiliki banyak kesamaan dengan kota-kota besar di Indonesia sehingga pembaca sejenak akan lupa kalau latar kisah Murad itu berada ribuan kilometer dari Indonesia. Tidak heran rasanya kalau Casablanca ini merupakan sister city dari Jakarta, yang suasana kota dan perilaku korupsi pegawai negerinya memiliki kesamaan.

Latar cerita dua novel Korupsi tersebut berada di Jakarta, dan di Maroko memberikan gambaran bahwa seorang pegawai pemerintahan yang bekerja dan tinggal di ibu kota banyak menghadapi tantangan demi menjaga kehormatan daripada pegawai yang tinggal di daerah. Oleh karena itu, mereka akan berusaha sekuat tenaga untuk menaikkan citra diri sebagai orang yang berhasil secara materi. Kesejajaran antara realitas dalam karya sastra dengan kehidupan nyata yang dialami oleh pengarang menunjukan adanya klise, dan karya sastra dapat dianggap sebagai dokumen.

Korupsi merupakan produk dari sikap hidup satu kelompok masyarakat yang memakai uang sebagai standar kebenaran dan sebagai kekuasaan mutlak. Akibatnya, kaum koruptor yang kaya raya dan para politisi korup yang berkelebihan uang bisa masuk ke dalam golongan elit yang berkuasa dan sangat dihormati. Mereka ini juga akan menduduki status sosial yang tinggi di mata masyarakat. 


\section{DAFTAR PUSTAKA}

Alatas, Syed Hussein. 1987. Korupsi: Sifat, Sebab dan Fungsi. Jakarta: LP3ES.

Benveniste, Guy. 1989. Birokrasi. Jakarta: RajaGrafindo Persada.

Damono, Sapardi Djoko. 1979. Sosiologi Sastra: Sebuah Pengantar Ringkas. Jakarta: Pusat Pembinaan dan Pengembangan Bahasa, Departemen Pendidikan dan Kebudayaan.

Hamzah, A. 1985. Korupsi : Dalam Pengelolaan Proyek Pembangunan. Jakarta: Akademika Pressindo.

Hasibuan, Albert. 1997. Titik Pandang untuk Orde Baru. Jakarta: Pustaka Sinar Harapan.

Jelloun, Tahar Ben. 2010. Korupsi. Penerjemah: Okke K.S. Zaimar. Jakarta: Serambi.

Kuntowijoyo. 1994. Demokrasi \& Budaya Birokrasi. Yogyakarta: Yayasan Bentang Budaya.

Kusuma, N dan Fitria Agustina. 2003. Gelombang Perlawanan Rakyat; Kasus-Kasus Gerakan Sosial di Indonesia. Yogyakarta: INSIST Press.

Toer, Pramoedya Ananta. 2002. Korupsi. Jakarta: Hasta Mitra.

Zon, Fadli. 2004. Politik Huru-Hara Mei 1998. Jakarta: Institute for Policy Studies. 